\title{
Pharyngeal Lipase and Digestion of Dietary Triglyceride in Man
}

\author{
Margit Hamosh, Hayden L. Klaeveman, Robert O. Wolf, and \\ ROBERT O. SCOW \\ From the Laboratory of Nutrition and Endocrinology and the Digestive and \\ Hereditary Diseases Branch, National Institute of Arthritis, Metabolism \\ and Digestive Diseases, and the Laboratory of Oral Medicine, National \\ Institute of Dental Research, Bethesda, Maryland 20014
}

A B S T R A C T Lipolytic activity was studied in esophageal and gastric aspirates obtained with a nasogastric tube from 14 healthy adult subjects. Samples were collected from esophagus, first at $30-35 \mathrm{~cm}$ and then at $40-45 \mathrm{~cm}$ from the nose, as the subject, after drinking 15-30 $\mathrm{ml}$ of a cream-milk mixture, swallowed small amounts of water. The samples from stomach were taken last and usually contained a small amount of cream-milk mixture. Lipolytic activity was assayed using chylomicron, milk, and corn oil triglyceride as substrate. Esophageal and gastric samples both contained lipolytic activity which hydrolyzed long-chain triglyceride to diglyceride, monoglyceride, and FFA, had a $\mathrm{pH}$ optimum of 5.4, and was not affected by either $0.5 \mathrm{M} \mathrm{NaCl}$ or $4 \mathrm{mM}$ sodium taurodeoxycholate. The activity, expressed as nanomoles of chylomicron triglyceride hydrolyzed per milliliter per minute, ranged from 0 to 145 in upper esophageal, 5 to 303 in lower esophageal, and 50 to 357 in gastric samples. Only a trace of lipolytic activity was found at $\mathrm{pH} 5.4$ in saliva collected from the parotid, submandibular, and sublingual glands, thus excluding those tissues as a source of the activity found in esophageal and gastric aspirates. The findings suggest that in man glands in or near the pharynx secrete a lipase that acts in the stomach to hydrolyze long-chain triglyceride to partial glycerides and FFA. It is proposed that this reaction is the first step in the digestion of dietary fat and that the amphi-

This work was presented in part at the Annual Meeting of the American Federation for Clinical Research, Atlantic City, 4-6 May 1974.

Dr. Hamosh's present address is: Department of Anatomy, Georgetown University Medical School, Washington, D. C. 20007. Dr. Klaeveman's present address is: Department of Medicine, University of California Medical Center, San Francisco, Calif. 94143.

Received for publication 4 June 1974 and in revised form 20 December 1974. philic lipids formed by lipolysis facilitate the emulsification of triglyceride in the stomach.

\section{INTRODUCTION}

A potent lipase, which hydrolyzes triglyceride to diglyceride, monoglyceride, and FFA at $\mathrm{pH}$ 4.5-5.4, was recently found in serous glands of the tongue in rat (1). A similar activity was also found in the soft palate, anterior oral pharyngeal wall, and lateral oral pharyngeal glands. The studies also showed that dietary triglycerides are readily hydrolyzed in the stomach to partial glycerides and FFA and that this reaction is catalyzed by the lingual lipase (1).

Intragastric hydrolysis of long-chain triglycerides has also been observed in man (2), dog (3), and calf (4), but the source of the activity was determined only in calf. The lipolytic activity in calf, called "pregastric esterase," was found in glandular tissue of the tongue, pharynx, and upper esophagus and in ingesta from the lower esophagus (5). The present study demonstrates in man a lipolytic activity in esophageal aspirates, which resembles closely that in stomach and, also, that in rat tongue (1).

\section{METHODS}

Subjects. 11 Female (20-22 yr) and six male (20-54 yr) normal volunteers were subjects for this study. They were on a regular diet with a daily intake of $1,200-1,500$ $\mathrm{kcal}$ for female and 2,500-3,500 kcal for male volunteers. Each subject was tested after an overnight fast.

Collection of samples. Esophageal and gastric aspirates were obtained with a rubber Levine tube, French gauge no. 16 (Argyle Scotsman Cat. no. MAR 2670-16, Health and Science Division, Brunswick Corp., Chicago), inserted through the nose. The tube was shortened by $9 \mathrm{~cm}$, measured from the pointed end, so that it would have a single lateral opening $1 \mathrm{~cm}$ from the tip. The tip of the tube was positioned at $30-35$ and at $40-45 \mathrm{~cm}$ from the nose for esophageal samples, and in the fundus for gastric samples. No topical anesthesia was used. Esophageal samples were 
TABLE I

Hydrolysis of Chylomicron Triglyceride In Vitro by Esophageal and Gastric Aspirates

\begin{tabular}{|c|c|c|c|c|c|c|c|c|c|}
\hline \multirow[b]{5}{*}{ Source of sample } & \multirow[b]{5}{*}{$\begin{array}{l}\mathrm{pH} \text { of } \\
\text { sample }\end{array}$} & \multicolumn{8}{|c|}{ Hydrolysis of chylomicron triglyceride } \\
\hline & & \multirow[b]{4}{*}{$\begin{array}{l}\text { No. of } \\
\text { subjects }\end{array}$} & \multirow[b]{4}{*}{$\begin{array}{c}\text { Amount } \\
\text { hydrolyzed }\end{array}$} & \multicolumn{2}{|c|}{ At pH 5.4} & & & \multirow{3}{*}{\multicolumn{2}{|c|}{ At $\mathrm{pH} 7.4$}} \\
\hline & & & & \multicolumn{4}{|c|}{ Products of hydrolysis } & & \\
\hline & & & & & & & FEA & & \\
\hline & & & & Diglyceride & $\begin{array}{l}\text { Mono- } \\
\text { glyceride }\end{array}$ & Glycerol & $\begin{array}{l}\text { (Calcu- } \\
\text { lated) }\end{array}$ & $\begin{array}{l}\text { No. of } \\
\text { subjects }\end{array}$ & $\begin{array}{c}\text { Amount } \\
\text { hydrolyzed }\end{array}$ \\
\hline & & & $\begin{array}{l}n m o l / m l \\
\text { per min }\end{array}$ & \multicolumn{3}{|c|}{ mol\% of glyceryl products } & $\begin{array}{c}\text { mol\% } \\
\text { of acyl } \\
\text { products }\end{array}$ & & $\begin{array}{l}\text { nmol } / \text { ml } \\
\text { per min }\end{array}$ \\
\hline $\begin{array}{l}\text { Upper esophagus } \\
\text { (30-35 cm from nose) }\end{array}$ & $6.0-7.5$ & 14 & $\begin{array}{c}29 \\
(0-145) *\end{array}$ & $77.9 \pm 2.7$ & $20.8 \pm 1.4$ & $1.3 \pm 0.9$ & 39 & 6 & $0.8 \pm 0.5$ \\
\hline $\begin{array}{l}\text { Lower esophagus } \\
\qquad(40-45 \mathrm{~cm} \text { from nose })\end{array}$ & $5.5-7.0$ & 13 & $\begin{array}{c}78 \\
(5-303)\end{array}$ & $75.9 \pm 3.9$ & $21.0 \pm 2.7$ & $3.1 \pm 1.4$ & 43 & 5 & $0.8 \pm 0.8$ \\
\hline $\begin{array}{l}\text { Stomach } \\
\qquad(60 \mathrm{~cm} \text { from nose })\end{array}$ & $3.0-5.0$ & 12 & $\begin{array}{c}240 \\
(50-357)\end{array}$ & $67.3 \pm 3.0$ & $25.5 \pm 2.3$ & $7.2 \pm 1.4$ & 47 & 9 & $2.7 \pm 0.3$ \\
\hline
\end{tabular}

The esophageal samples were aspirated with a nasogastric tube while the subject, after drinking $15-30 \mathrm{ml}$ of a cream-milk mixture, swallowed $15-45 \mathrm{ml}$ of water; the samples analyzed were water-clear. The gastric samples, which were taken last, usually contained small amounts of cream-milk and had a triglyceride content of $1.5-5.0 \mu \mathrm{mol} / \mathrm{ml}$. A mixture of $0.1-0.25 \mathrm{ml}$ of sample, $0.25 \mathrm{ml}$ of $10 \%$ albumin-buffer solution containing $2 \mu \mathrm{mol}$ of doubly labeled chylomicron triglyceride ( $\left.{ }^{3} \mathrm{H}\right]$ glycerol and $\left[{ }^{14} \mathrm{C}\right]$ palmitic acid), and water to a final volume of $0.5 \mathrm{ml}$ was incubated $15-60 \mathrm{~min}$ at $38^{\circ} \mathrm{C}$. The duration of incubation depended on the amount of activity present in the sample; gastric samples assayed at pH 5.5 were usually incubated 15 min, whereas the other samples were incubated 15 and $60 \mathrm{~min}$. Values are means $\pm \mathrm{SE}$. The procedures for measuring glycerides and glycerol, and for calculating the amount of FFA formed are given in the Methods section.

* Range of values observed in group.

obtained at each level while the subject swallowed 15-30 $\mathrm{ml}$ of a cream-milk mixture (half-and-half, purchased from local food markets) and then $15-45 \mathrm{ml}$ of water, until the samples were clear; only clear esophageal samples were assayed for lipolytic activity. The gastric sample, which was taken last, usually contained a small amount of cream-milk and had a triglyceride content ranging from 1.5 to 5.0 $\mu \mathrm{mol} / \mathrm{ml}$. Samples were collected with the aid of a manually operated vacuum pump (Nalge Company, Division of Sybron Corp., Rochester, N. Y.) into $20 \mathrm{ml}$ glass vials and stored on ice until assayed.

Secretions of the major salivary glands were collected simultaneously for 20-60 min with devices placed bilaterally over the orifices of the parotid, submandibular, and sublingual ducts $(6,7)$. The glands were stimulated with application by the subject of small amounts of lemon juice to the tongue every $15 \mathrm{~s}$. Secretions were collected and stored separately in ice-cooled tubes and assayed 30-60 min later.

Assay of lipolytic activity. Lipolytic activity in esophageal, gastric, and salivary samples was measured by the amount of chylomicron triglyceride hydrolyzed to diglyceride, monoglyceride, glycerol, and FFA (1). The assay mixture contained 100-250 $\mu \mathrm{l}$ of sample, $2 \mu \mathrm{mol}$ of doubly labeled chylomicron triglyceride, $50 \mu 1$ of $1 \mathrm{M}$ sodium citrate- $\mathrm{Na}_{2} \mathrm{HPO}_{4}$ buffer solution ( $\mathrm{pH}$ 3.6-7.6), $200 \mu \mathrm{l}$ of $12.5 \%$ bovine serum albumin (Fraction V, Metrix, Armour

TABLE II

Hydrolysis of Chylomicron and Milk Triglyceride In Vitro by Secretions of Paratid, Submandibular, and Sublingual Glands

\begin{tabular}{|c|c|c|c|c|c|c|c|c|}
\hline \multirow{3}{*}{$\begin{array}{c}\text { Source of } \\
\text { sample }\end{array}$} & \multirow{3}{*}{$\begin{array}{c}\text { No. of } \\
\text { subjects }\end{array}$} & \multirow[b]{3}{*}{ Rate of secretion } & \multirow{3}{*}{$\begin{array}{l}\text { pH of } \\
\text { sample }\end{array}$} & \multicolumn{4}{|c|}{ Chylomicron triglyceride* } & \multirow{3}{*}{$\begin{array}{c}\text { Milk } \\
\text { triglyceride } \\
\text { Amount } \\
\text { hydrolyzed } \\
\text { at pH } 5.4\end{array}$} \\
\hline & & & & \multicolumn{2}{|c|}{ Amount hydrolyzed } & \multicolumn{2}{|c|}{ Glycerol produced } & \\
\hline & & & & At $\mathrm{pH} 5.4$ & At $\mathrm{pH} 7.5$ & At pH 5.4 & At $\mathrm{pH} 7.5$ & \\
\hline & \multicolumn{3}{|c|}{$\mathrm{ml} / \mathrm{min}$} & \multicolumn{2}{|c|}{$n m o l / m l$ per min } & \multicolumn{2}{|c|}{ mol\% of glyceryl products } & $n m o l / m l$ \\
\hline Parotid & 6 & $0.2-0.5$ & 7.0 & $1.8 \pm 0.5$ & $4.2 \pm 0.5$ & $47 \pm 3$ & $58 \pm 4$ & 0 \\
\hline Submandibular & 6 & $0.1-0.3$ & 7.0 & $2.0 \pm 0.7$ & $3.5 \pm 0.7$ & $50 \pm 8$ & $58 \pm 7$ & 0 \\
\hline Sublingual & 5 & $0.003-0.05$ & 7.0 & $0.7 \pm 0.3$ & $2.0 \pm 0.3$ & $44 \pm 10$ & $66 \pm 4$ & 0 \\
\hline
\end{tabular}

Secretions were collected bilaterally from parotid and submandibular glands for 20-30 min and from sublingual glands for 30-60 min. Values are means $\pm \mathrm{SE}$ * A mixture of $0.25 \mathrm{ml}$ of sample, $1 \mu \mathrm{mol}$ of doubly labeled chylomicron triglyceride, and $0.25 \mathrm{ml}$ of $10 \%$ albumin-buffer solution were incubated $30-60$ $\min$ at $38^{\circ} \mathrm{C}$.

¥ A mixture of $0.5 \mathrm{ml}$ of sample, $0.05 \mathrm{ml}$ of cream-milk (1:1) containing about $5 \mu \mathrm{mol}$ of triglyceride, and $0.5 \mathrm{ml}$ of $10 \%$ albumin-buffer solution were incubated $60 \mathrm{~m}^{1} \mathrm{n}$ at $38^{\circ} \mathrm{C}$ 


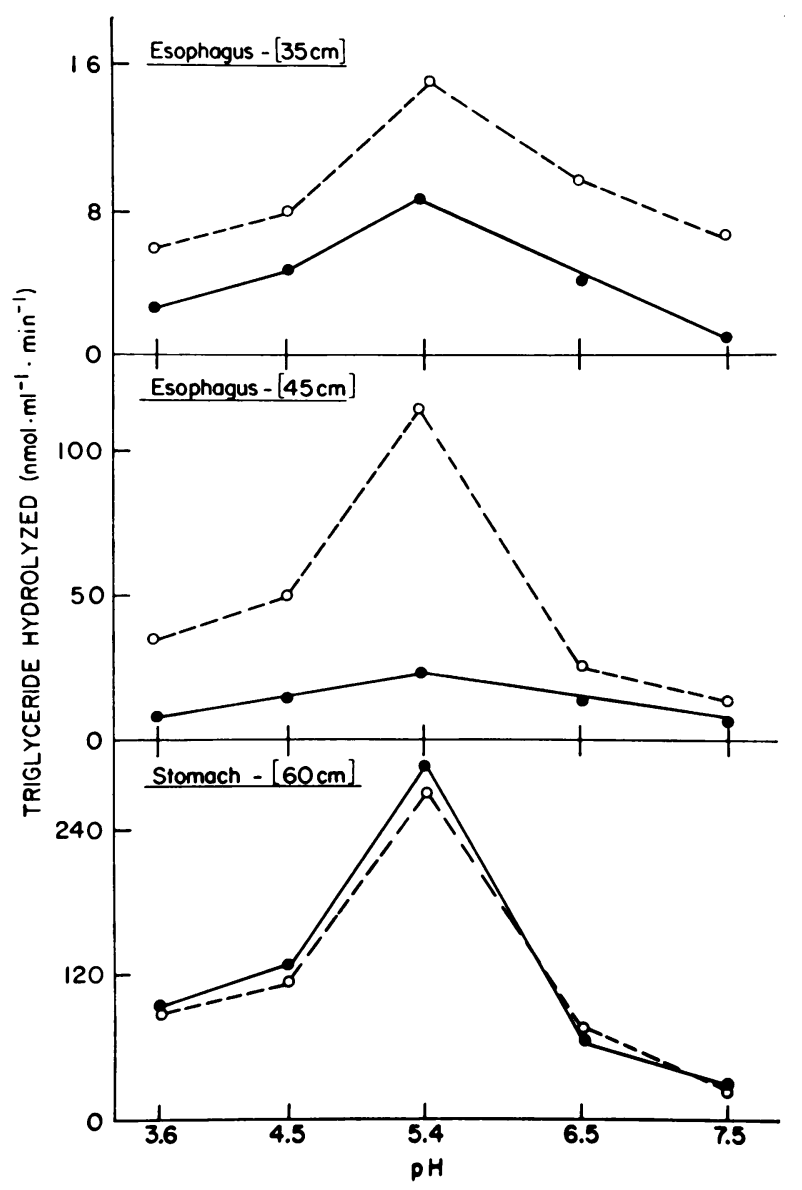

Figure 1 Effect of $\mathrm{pH}$ on the hydrolysis of chylomicron triglyceride by aspirates obtained from the esophagus and stomach of two normal subjects. Samples were incubated 15 $\min$ at $37^{\circ} \mathrm{C}$.

Pharmaceutical Company, Chicago, Ill., lot G36912) solution, and water to a final volume of $500 \mu \mathrm{l}$. The chylomicrons were isolated by centrifugation from thoracic duct chyle of fasted rats tube fed corn oil containing $\left[1-{ }^{14} \mathrm{C}\right]-$ palmitic acid and trioleoyl- $\left[2-{ }^{8} \mathrm{H}\right]$ glycerol and suspended in $4 \%$ albumin solution (1). The assay mixture was incubated in polypropylene tubes (Falcon Plastics, Division of BioQuest, Oxnard, Calif.) at $38^{\circ} \mathrm{C}$ for $15-60 \mathrm{~min}$ in a Dubnoff shaking bath. Lipids in the incubation mixture were extracted by a modification of the procedure of Dole and Meinertz (8), substituting hexane for heptane (9). Lipids in the hexane extract were separated by thin-layer chromatography (10) and analyzed for ${ }^{3} \mathrm{H}$ and ${ }^{14} \mathrm{C}$ content (1). The amount of glycerol formed was calculated from either the decrease in ratio of ${ }^{8} \mathrm{H}$ to ${ }^{14} \mathrm{C}$ in the hexane extract of the assay mixture (11) or from the amount of $\left[{ }^{3} \mathrm{H}\right]$ glycerol produced during incubation (1). The proportions of tri-, di-, and monoglyceride in lipid samples were calculated from the distribution of $\left[{ }^{3} \mathrm{H}\right]$ glycerol among the three classes of lipids. The amount of FFA formed was calculated from the amount of triglyceride (TG) hydrolyzed and the relative amounts of diglyceride (DG), monoglyceride $(\mathrm{MG})$, and glycerol (G) formed during lipolysis (Table
I) : FFA formed $(\mu \mathrm{mol})=$ TG hydrolyzed $(\mu \mathrm{mol}) \times(\%$ $\left.\mathrm{DG}+\left[\begin{array}{ll}\% & \mathrm{MG} \times 2\end{array}\right]+\left[\begin{array}{ll}\% & \mathrm{G} \times 3\end{array}\right]\right)$.

When nonradioactive lipids were used, as in Table II and III, the hexane extract of lipids was carefully washed with blank aqueous phase (isopropanol-water) to remove short-chain fatty acids and other acidic contaminants (8). FFA in the hexane extract were measured by titration (9), and glycerides were separated by column chromatography (1) and measured by the method of Rapport and Alonzo (12).

\section{RESULTS}

Lipolytic activity in esophageal and gastric aspirates. Esophageal and gastric aspirates were obtained with a nasogastric tube from normal subjects fasted overnight. Samples for analyses were collected from esophagus, first at $30-35 \mathrm{~cm}$ and then at $40-45 \mathrm{~cm}$ from the nose, as the subject, after drinking $15-30 \mathrm{ml}$ of a cream-milk mixture, swallowed small amounts of water. Usually only $10-20 \%$, but sometimes up to $50 \%$, of the water swallowed was recovered from the esophagus. The esophageal samples used for analyses were water-clear. Samples from stomach, which were taken last, contained small amounts of the cream-milk mixture and had a triglyceride content of $1.5-5.0 \mu \mathrm{mol} / \mathrm{ml}$. The $\mathrm{pH}$ of samples from the upper esophagus ranged 6.0-7.5, from the lower esophagus, 5.5-7.0, and from stomach, 3.05.0 (Table I).

Aspirates from both esophagus and stomach contained lipolytic activity that hydrolyzed chylomicron triglyceride at $\mathrm{pH} 5.4$ to mostly partial glycerides and FFA (Table I). The glyceryl products formed averaged $67-78 \%$ diglycerides, $21-26 \%$ monoglycerides, and $<8 \%$ glycerol. The lipolytic activity in samples from the upper esophagus hydrolyzed $0-145$, from the lower esophagus, 5-303, and from stomach, 50-357 nmol of chylomicron triglyceride/ml per min (Table I). Since milk triglyceride in gastric samples probably competed with chylomicron triglyceride for enzyme, the rate observed with chylomicrons (Table I) may be an underestimate of the lipolytic activity in samples from the stomach. The lipolytic activity in esophageal and gastric aspirates was not affected by either $0.5 \mathrm{M} \mathrm{NaCl}$ or $4 \mathrm{mM}$ sodium taurodeoxycholate. The results obtained in two subjects show that the lipolytic activity in esophageal and gastric samples had the same $\mathrm{pH}$ optimum, 5.4 (Fig. 1).

To test whether the major salivary glands could be a source of the lipolytic activity present in esophageal and gastric aspirates, secretions were collected from the parotid, submandibular, and sublingual glands of six subjects and tested for lipolytic activity (Table II). Salivary secretions had only a trace of lipolytic activity at $\mathrm{pH} 5.4$, hydrolyzing $<2 \mathrm{nmol}$ of chylomicron triglyceride/ml per min and 0 nmol of milk triglyceride. The lipolytic activity in saliva, in contrast to that in 
TABLE III

Hydrolysis of Milk and Corn Oil Triglyceride in the Stomach

\begin{tabular}{|c|c|c|c|c|c|c|c|c|}
\hline \multirow[b]{2}{*}{ Test meal and sample } & \multirow[b]{2}{*}{$\begin{array}{l}\text { Time after } \\
\text { test meal }\end{array}$} & \multirow[b]{2}{*}{$\mathrm{pH}$} & \multirow[b]{2}{*}{ Volume } & \multirow[b]{2}{*}{$\begin{array}{l}\text { Glyceride } \\
\text { concentra- } \\
\text { tion }\end{array}$} & \multicolumn{4}{|c|}{ Lipid composition } \\
\hline & & & & & Triglyceride & Diglyceride & $\begin{array}{c}\text { Mono- } \\
\text { glyceride }\end{array}$ & FFA \\
\hline & $\min$ & & $m l$ & $m M$ & \multicolumn{3}{|c|}{ mol\% of total glyceride } & $\begin{array}{c}\text { mol\% of } \\
\text { total fatty } \\
\text { acids }\end{array}$ \\
\hline \multicolumn{9}{|l|}{ Cream-milk mixture A } \\
\hline Meal & - & 7.0 & - & 110 & 97.7 & 2.4 & 0 & 0 \\
\hline \multicolumn{9}{|l|}{ Gastric contents } \\
\hline \multirow[t]{3}{*}{ Subject I } & 0 & 5.0 & 20 & 2 & - & - & 一 & - \\
\hline & 1 & 5.0 & 15 & 55 & 86.3 & 12.7 & 1.0 & 3.3 \\
\hline & 10 & 5.0 & 30 & 9 & 90.9 & 7.7 & 1.3 & 1.7 \\
\hline \multirow[t]{3}{*}{ Subject II } & 0 & 4.0 & 25 & 0.4 & - & - & - & - \\
\hline & 1 & 4.5 & 20 & 15 & 84.4 & 14.0 & 1.6 & 4.5 \\
\hline & 10 & 4.5 & 35 & 4 & 89.0 & 10.0 & 1.0 & 3.0 \\
\hline \multicolumn{9}{|l|}{ Cream-milk mixture B } \\
\hline Meal & - & 6.8 & - & 130 & 95.0 & 4.3 & 0.7 & 0.9 \\
\hline \multicolumn{9}{|l|}{ Gastric contents } \\
\hline \multirow[t]{3}{*}{ Subject III } & 0 & 5.0 & 15 & 0.2 & - & - & - & - \\
\hline & 3 & 5.0 & 20 & 19.0 & 92.5 & 6.9 & 0.4 & 1.5 \\
\hline & 5 & 5.0 & 20 & 26.0 & 91.0 & 7.5 & 0.8 & 1.7 \\
\hline \multirow[t]{3}{*}{ Subject IV } & 0 & 5.5 & 12 & 0.1 & - & - & - & - \\
\hline & 1 & 5.8 & 18 & 5.4 & 87.6 & 11.0 & 0.8 & 4.5 \\
\hline & 5 & 5.8 & 10 & 3.7 & 83.5 & 14.6 & 1.6 & 6.0 \\
\hline \multicolumn{9}{|l|}{ Corn oil-water mixture* } \\
\hline Meal & - & 3.0 & - & 109 & 94.0 & 5.9 & 0.8 & 0.3 \\
\hline \multicolumn{9}{|l|}{ Gastric contents } \\
\hline \multirow[t]{3}{*}{ Subject V } & 0 & 5.5 & 10 & 0.5 & - & 一 & - & - \\
\hline & 1 & 3.0 & 18 & 15.7 & 91.0 & 8.1 & 0.8 & 0.8 \\
\hline & 3 & 3.0 & 20 & 9.3 & 89.5 & 9.0 & 1.3 & 2.5 \\
\hline \multirow[t]{2}{*}{ Subject VI } & 0 & 6.0 & 6 & 0.1 & - & - & - & - \\
\hline & 3 & 4.0 & 15 & 7.2 & 89.0 & 9.3 & 1.2 & 1.6 \\
\hline \multirow[t]{3}{*}{ Subject VII } & 0 & 5.8 & 40 & 0.3 & - & - & - & - \\
\hline & 4 & 3.5 & 30 & 2.8 & 88.0 & 9.2 & 2.4 & 4.3 \\
\hline & 6 & 3.5 & 30 & 2.9 & 87.0 & 10.0 & 2.6 & 4.6 \\
\hline
\end{tabular}

Subjects I-VI drank $30 \mathrm{ml}$, and subject VII drank $60 \mathrm{ml}$ of the test meal after fasting overnight. Gastric samples were aspirated with a nasogastric tube before and at various times after the meal. The gastric samples taken from subjects I and II were placed immediately on ice, and aliquots were taken for analyses within $15 \mathrm{~min}$ after collection, whereas aliquots of samples collected from the other subjects were put immediately into hexane-isopropanol for analyses (9).

* Lemon juice was added to the corn oil-water mixture to make it more palatable. Incubation at $38^{\circ} \mathrm{C}$ for $1 \mathrm{~h}$ had no effect on the FFA content of the mixture.

esophageal and gastric aspirates, was slightly higher at $\mathrm{pH} 7.5$ than at $\mathrm{pH} 5.4$, and produced proportionally more glycerol, $>44$ vs. $<8$ mol\% of glyceryl products (Tables I and II). Thus, it seems unlikely that salivary glands are the source of the lipolytic activity found in esophageal and gastric aspirates.

Intragastric lipolysis of milk and corn oil triglyceride was studied in seven subjects fasted overnight. Samples of gastric contents were taken immediately before and at various times up to $10 \mathrm{~min}$ after the subjects drank 30 or $60 \mathrm{ml}$ of a liquid test meal containing $11-13 \%$ triglyceride. The results show that $3-12 \%$ of the tri- glyceride was hydrolyzed within $4 \mathrm{~min}$ to diglyceride, monoglyceride, and FFA, and that hydrolysis did not continue appreciably beyond that time (Table III). The results also show that corn oil triglyceride was hydrolyzed in the stomach as quickly as milk triglyceride. Proportionally less monoglyceride was formed by lipolysis in the stomach in vivo (Table III) than in gastric aspirates assayed in vitro (Table I). This difference, as well as the limitation of lipolysis in vivo with time, may be due to the lack of FFA acceptor, such as albumin, in the test meals.

The effect of simulated products of intragastric 
TABLE IV

Effect of Simulated Lipolytic Products on the Emulsification of Glyceride at pH 5.4 in $1 \%$ Gelatin Solution

\begin{tabular}{|c|c|c|c|c|c|c|c|}
\hline \multicolumn{5}{|c|}{ Lipid composition } & & & \\
\hline \multirow{3}{*}{ Triolein } & \multirow{3}{*}{$\begin{array}{c}\text { Diolein } \\
\% \text { of total glyceric }\end{array}$} & \multirow{3}{*}{ Monoolein } & \multirow{3}{*}{$\begin{array}{l}\text { Oleic acid } \\
\% \text { of total } \\
\text { fatty acids }\end{array}$} & \multirow{3}{*}{$\begin{array}{l}\text { Total fatty } \\
\text { acid con- } \\
\text { centration } \\
\quad m M\end{array}$} & \multicolumn{3}{|c|}{ Lower half of suspension $15 \mathrm{~min}$ after mixing } \\
\hline & & & & & \multirow{2}{*}{$\begin{array}{c}\text { Turbidity } \\
O D \text { at } 550 \mathrm{~nm}\end{array}$} & \multicolumn{2}{|c|}{ Glyceride fatty acid concentration* } \\
\hline & & & & & & $m M$ & $\begin{array}{l}\% \text { of total fatty } \\
\text { acid concentration }\end{array}$ \\
\hline 100 & 0 & 0 & 0 & 11.7 & $0.32 \pm 0.05$ & $0.71 \pm 0.17$ & $6.1 \pm 1.4$ \\
\hline 86 & 11.6 & 2.3 & 3.7 & 11.7 & $0.86 \pm 0.01$ & $1.84 \pm 0.09$ & $15.7 \pm 0.8$ \\
\hline 71 & 24.1 & 4.9 & 7.6 & 11.7 & $1.15 \pm 0.13$ & $2.52 \pm 0.3$ & $21.5 \pm 2.6$ \\
\hline
\end{tabular}

The lipids were added in the amounts indicated to $1 \%$ gelatin in phosphate buffer solution at $\mathrm{pH} 5.4$ in disposable glass test tubes, warmed to $38^{\circ} \mathrm{C}$, mixed for 1 min with a Vortex shaker set at 5 (Vortex-Genie, model K-550-G, Scientific Industries, Inc., Springfield, Mass.), and left standing at room temperature for $15 \mathrm{~min}$. Turbidity was then measured in a Beckman model B spectrophotometer (Beckman Instruments, Inc., South Pasedena, Calif.) and an aliquot $(3 \mathrm{ml})$ equal to half of the suspension was taken from the lower part of the tube for analyses (12).

* Column chromatography (1) showed that the glyceride composition was the same as that of the total suspension.

lipolysis on the emulsification of triglyceride was examined by replacing triglyceride with various amounts of partial glycerides and FFA in $1 \%$ gelatin solution at $\mathrm{pH}$ 5.4. The quantitative relationship between diglyceride, monoglyceride, and FFA added to the mixture was the same as that found in stomach contents (Table III). Emulsification was measured by the degree of turbidity and the amount of glyceride fatty acid present in the lower half of the aqueous suspension 15 min after mixing with a Vortex shaker. The results show that replacement of tryglyceride with partial glycerides and FFA aids dispersion of the lipid in an aqueous solution at $\mathrm{pH} 5.4$ (Table IV). These findings indicate that products of intragastric lipolysis could be expected to facilitate emulsification of triglyceride in the stomach.

\section{DISCUSSION}

Although it is generally thought that enzymic digestion of fat begins in the duodenum $(13,14)$, several studies have shown that dietary triglyceride is readily hydrolyzed in the stomach to FFA and partial glycerides (1-3, 15, Table III). Furthermore, gastric juice collected free of bile from subjects fasted overnight contains lipolytic activity that hydrolyzes at $\mathrm{pH}<6$ longchain triglycerides of milk, various vegetable oils, and animal fats to partial glycerides and FFA $(16,17)$. Similar lipolytic activity was found in gastric juice of infants (15) and in gastric contents of suckling and adult rats $(1,15)$. Lipolytic activity has been demonstrated histochemically in rat gastric mucosa (18), but the activity found in homogenates of the mucosa had very little effect on long-chain triglyceride (19).

Our studies show that esophageal aspirates obtained from adult subjects contain lipolytic activity (Table I) similar to that found in homogenates of tongue and other pharyngeal tissues of the rat (1). The activity hydrolyzed at $\mathrm{pH} 5.4$ long-chain triglyceride to diglyceride, monoglyceride, and FFA (Table I) and was not affected by either $0.5 \mathrm{M} \mathrm{NaCl}$ or $4 \mathrm{mM}$ sodium taurodeoxycholate. Lipolytic activity was negligible at $\mathrm{pH} 5.4$ in secretions collected from the parotid, submandibular, and sublingual glands (Table II), excluding those tissues as a source of the lipolytic activity present in esophageal aspirates. Lipolytic activity was similarly absent from the major salivary glands in rat (1). The findings suggest that glands in or near the pharynx in man secrete a lipase that hydrolyzes triglyceride to partial glycerides and FFA at $\mathrm{pH}$ 5.4.

Lipolytic activity in gastric contents is markedly reduced when pharyngeal secretions are excluded from the stomach in rats (1) and calves (4). The close similarity in lipolytic activity between esophageal and gastric aspirates in our adult subjects (Table I) suggests that the source of gastric lipolytic activity in man may also be the pharynx. The above findings suggest that a lipase is secreted by pharyngeal tissues which hydrolyzes in the stomach long-chain triglyceride to partial glycerides and FFA. It is proposed that this reaction is the first step in the digestion of dietary fat in man and that the amphiphilic lipids (20) formed, particularly monoglyceride and FFA, facilitate the emulsification of triglyceride in the stomach (13).

\section{REFERENCES}

1. Hamosh, M., and R. O. Scow. 1973. Lingual lipase and its role in the digestion of dietary fat. J. Clin. Invest. 52: 88-95.

2. Borgström, B., A. Dahlqvist, G. Lundh, and J. Sjövall. 1957. Studies of intestinal digestion and absorption in the human. J. Clin. Invest. 36: 1521-1536. 
3. Douglas, G. J., Jr., A. J. Reinauer, W. C. Brooks, and J. H. Pratt. 1953. The effect on digestion and absorption of excluding the pancreatic juices from the intestine. Gastroenterology. 23: 452-459.

4. Ramsey, H. A., and J. W. Young. 1961. Role of pregastric esterase in the abomasal hydrolysis of milk fat in the young calf. J. Dairy Sci. 44: 2227-2231.

5. Ramsey, H. A., G. H. Wise, and S. B. Tove. 1956. Esterolytic activity of certain alimentary and related tissues from cattle in different age groups. J. Dairy Sci. 39 : 1312-1322.

6. Henriques, B. L., and H. H. Chauncey. 1961. A modified method for the collection of human submaxillary and sublingual saliva. Oral Surg. Oral Med. Oral Pathol. 14: 1124-1129.

7. Carlson, A. J., and A. L. Crittenden. 1910. The relation of ptyalin concentration to the diet and to the rate of secretion of the saliva. Am. J. Physiol. 26: 169-177.

8. Dole, V. P., and H. Meinertz. 1960. Microdetermination of long-chain fatty acids in plasma and tissues. $J$. Biol. Chem. 235 : 2595-2599.

9. Bieberdorf, F. A., S. S. Chernick, and R. O. Scow. 1970. Effect of insulin and acute diabetes on plasma FFA and ketone bodies in the fasting rat. J. Clin. Invest. 49 : 1685-1693.

10. Stein, O., R. O. Scow, and Y. Stein. 1970. FFA- ${ }^{8} \mathrm{H}$ uptake by perfused adipose tissue: electron microscopic autoradiographic study. Am. J. Physiol. 219: 510-518.

11. Hamosh, M., T. R. Clary, S. S. Chernick, and R. O. Scow. 1970. Lipoprotein lipase activity of adipose and mammary tissue and plasma triglyceride in pregnant and lactating rats. Biochim. Biophys. Acta. 210: 473482.

12. Rapport, M. M., and N. Alonzo. 1959. Photometric determination of fatty acid ester groups in phospholipides. J. Biol. Chem. 217: 193-198.

13. Senior, J. R. 1964. Intestinal absorption of fats. $J$. Lipid Res. 5 : 495-521.

14. Johnston, J. M. 1970. Intestinal absorption of fats. Compr. Biochem. 18: 1-18.

15. Olivecrona, T., O. Hernell, T. Egelrud, А. Billström, H. Helander, G. Samuelson, and B. Fredrikzon. 1973. Studies on the gastric lipolysis of milk lipids in suckling rats and in human infants. In Dietary Lipids and Postnatal Development. C. Galli, G. Jacini, and A. Pecile, editors. Raven Press, New York. 77-89.

16. Cohen, M., G. R. H. Morgan, and A. F. Hofmann. 1971. Lipolytic activity of human gastric and duodenal juice against medium and long chain triglycerides. Gastroenterology. 60 : 1-15.

17. Bank, S., L. H. Krut, I. N. Marks, B. Bronle-Stewart, and P. J. LeR. Uys. 1964. Hydrolysis of fat by human gastric juice. Gut. 5 : $480-484$.

18. Barrowman, J. A., and S. J. Darnton. 1970. The lipase of rat gastric mucosa. A histochemical demonstration of the enzymatic activity against a medium chain triglyceride. Gastroenterology. 59: 13-21.

19. Bennett Clark, S., B. Brause, and P. R. Holt. 1969. Lipolysis and absorption of rat in the rat stomach. Gastroenterology. 56: 214-222.

20. Small, D. M. 1968. A classification of biologic lipids based upon their interaction in aqueous systems. $J$. Am. Oil Chem. Soc. 45 : 108-117. 